\title{
Introduction to "Next Labour? Changes in British Union-Labour Party Relations Since the Election of Tony Blair"
}

\author{
Victor G. Devinatz ${ }^{1}$
}

Published online: 28 March 2019

(C) Springer Science+Business Media, LLC, part of Springer Nature 2019

Since the formation of national trade union movements, often dating back to the nineteenth century in many countries, there have been two branches of the labor movement - an economic arm represented by trade unions and a political arm represented by workers' political parties (Labor, Social Democratic and Communist). While these workers' parties in industrial and post-industrial nations reached their peak strength from 1940 to 1989 , their weakness in the last three decades has contributed to declining union densities in many countries. Beginning in the 1930s and 1940s, most Labor and Social Democratic political parties advocated social Keynesianism as their economic policy. However, with the increased globalization of capital, the advocacy of social Keynesianism began to become increasingly problematic in the 1970s. The movement away from this economic policy has caused increasing tension between the Labor and Social Democratic parties and their affiliated trade unions in the late 20th and early 21 st centuries.

In this timely, well-written and interesting "Perspectives" Section article, Dr. Jason Schulman, Adjunct Assistant Professor in the Department of Political Science at Lehman College, City University of New York, extends on some of the ideas first discussed in his excellent book, Neoliberal Labour Governments and the Union Response: The Politics of the End of Labourism (Palgrave Macmillan, 2015). In this essay, Schulman argues that the British Labour Party's support of neoliberal economic policies, which began under Tony Blair's government, resulted from the "shift to a more passive approach to union-party relations" on the part of the British trade union movement. Because of the trade union movement's defensiveness, Blair and his supporters were able to form "a close relationship with business" which led to the establishment of a "neoliberal power network" for implementing neoliberal economic policy. The unions' passivity continued under the regime of Gordon Brown and Ed Milliband. With the ascension of Jeremy Corbyn to the Labour Party's leadership and the party's success in a recent British general election, a different relationship emerged between

Victor G. Devinatz

vgdevin@ilstu.edu

1 Department of Management \& Quantitative Methods, Illinois State University,

Normal, IL 61790-5580, USA 
Corbyn and the trade union movement. Schulman discusses and analyzes the British trade unions' strategies given that the Labour Party leadership is now clearly pro-labor.

If any of the journal's readers are interested in responding to any essays published in the "Perspectives" Section or would like to write articles on any topics in the field of employee relations, please do not hesitate to contact me with your proposal. I welcome both practitionerbased and scholarly-based articles written from any one of a variety of theoretical perspectives. I hope that you enjoy this article and find it most illuminating.

Publisher's Note Springer Nature remains neutral with regard to jurisdictional claims in published maps and institutional affiliations. 